ЕКОНОМІЧНА ТА СОЦАЛЬНА ГЕОГРАФІЯ І ТУРИЗМ

\author{
УДК 911.3:32
}

DOI: $10.18524 / 2303-9914.2018 .2(33) .146634$

M. P. Dobysh, Ph.D. student

Taras Shevchenko National University of Kyiv, Glushkova avenue, 2, Kyiv, 03127, Ukraine

mpetrovych@gmail.com

\title{
TERRITORIAL PATTERNS OF TURNOUT AND REPRESENTATION IN PARLIAMENTARY ELECTIONS 2002-2014 IN UKRAINE
}

\begin{abstract}
Problem Statement and Purpose. Geography of turnout is in the periphery of the geographical studies of elections. However, recent studies of the geographical patterns of the turnout decline and dynamics in Western countries reveal the importance of the understanding of the time and place-specific contexts of the decisions to vote or not to vote. There are no studies dedicated to the geography of turnout in Ukraine; therefore, the paper aims to fill the gap and start a discussion of territorial patterns of turnout in parliamentary elections in the country in 2002-2014.

Data \& Methods. The paper examines the geography of turnout in Ukraine based on the data at the polling stations level and administrative rayons $(\mathrm{n}=490)$ and cities with special administrative status $(\mathrm{n}=183)$ level for parliamentary elections of 2002, 2006, 2007, 2012, and 2014. The cartographic analysis was conducted for the turnout at polling stations level and geography of the votes for the parties under the threshold at rayon and cities with special administrative status level.

Results. The analysis reveals that South and East Ukraine has significantly lower turnout, which became more vivid after 2002 elections, cities in Ukraine have essentially lower turnout than the periphery, and territories with higher shares of national minorities also have lower turnout. The situation is complicated by the higher level of support for parties, which did not reach the threshold on proportional voting in 2014 parliamentary elections in the South and East Ukraine, and higher support of such parties in the territories with higher shares of national minorities in 2002-2014. The paper also reveals that the gap in turnout between urban and rural areas was declining in 2002-2014 because of the lower level of turnout decline in cities. Moreover, in 2006 parliamentary elections, turnout in cities with special administrative status increased despite continuous decline in the periphery. We also start a discussion about the causes and consequences of the territorial patterns in turnout and its dynamics in Ukraine.
\end{abstract}

Keywords: turnout decline, geography of turnout, geography of representation, territorial patterns of turnout in Ukraine. 


\section{INTRODUCTION}

Problem statement. Electoral geography is focused on the studies of territorial patterns of voting behavior, geographical factors that influence elections outcomes, geography of representation, and electoral dynamics $[1,2,16,29]$. However, the geography of representation is narrowed to the understanding of manipulations of constituency boundaries in favor of one of the political parties (known as gerrymandering) and manipulation of electoral law and electoral systems engineering to favor particular political powers. At the same time, the primary question about who and why vote and who and why abstain is on the periphery of geographical studies. Although, Johnston and Pattie [14] show that geography of turnout should be analyzed for the better understanding of the electoral geography of the country. Moreover, the geography of representation is not focused on the geographical distribution of the votes that were given for parties who did not reach a threshold and political effects of that distribution and its dynamics over time.

Literature review. The main problem that concerns scholars of turnout is decreasing participation in elections. Despite it differs among countries in the world, and Norris [23] assumes that it is the issue of socio-economic development and only developed Western democracies face dramatic changes in turnout, turnout in young Ukrainian democracy and developing Ukrainian state is also decreasing (Fig. 1). Several theories emerged to explain why people are not attending elections. Political participation is widely assumed to be influenced by available resources (education, income, and time) and those who have mentioned resources are more likely to participate $[24 ; 28]$. Therefore, some of the voters who are not attending elections

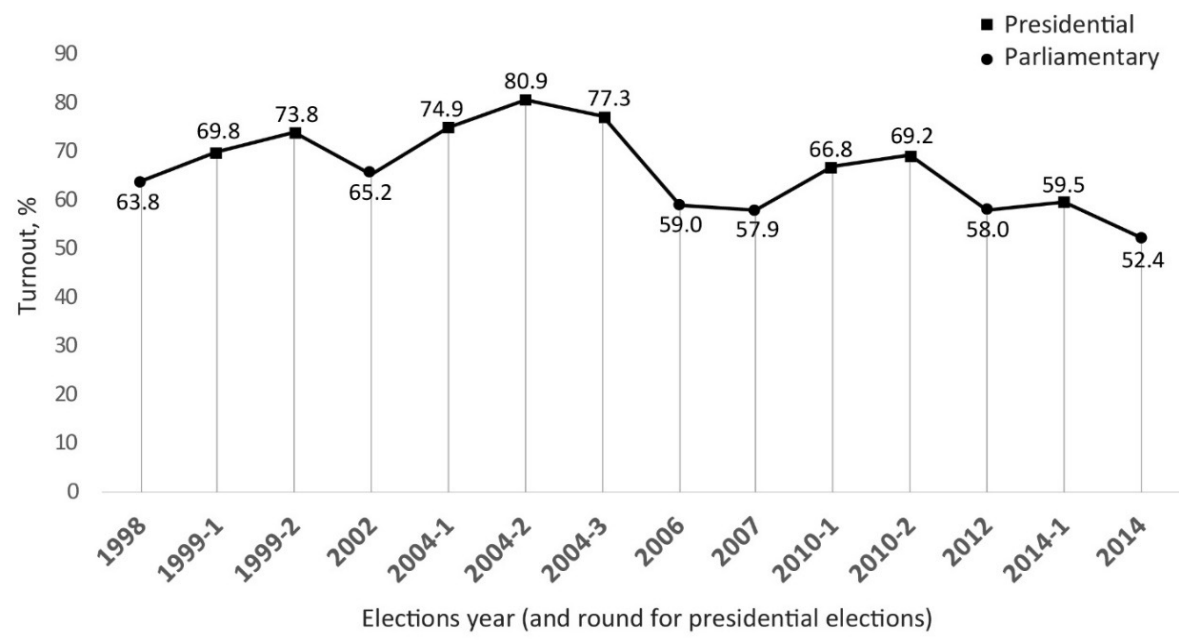

Fig. 1. Turnout dynamics in Ukraine in parliamentary and presidential elections in 1998-2014 (based on data from Central Electoral Office) 
might have no time, lower education and consequently less interest in politics or being in poverty might be alienated from politics. However, the level of education is rising in recent years as well as incomes are increasing. Consequently, education and income influencing turnout have no explanatory power for the decline in electoral participation.

Johnston and Pattie [14] assume that decline in trust to politicians might cause changes in turnout. Moreover, they suggest that the crisis of electoral participation as a particular mode of political engagement may also influence the decrease in turnout $[14$, p. 232]. For instance, voters who thought that Labour and Conservative parties in the UK had become less different in 1992-1997 had two times lower turnout rates than those who felt that parties become more distinctive [14, p. 242]. In the studies of elections and public opinion in Great Britain, there is also evidence that decline in turnout is not because of lower interest in politics [5]. On the other hand, Franklin $[10,11]$, suggests that decline in turnout in Western countries is due to the character of elections, especially decrease in the voting age from 21 to 18 . He assumes that young people who abstained in three elections are unlikely ever to have a voting habit [11].

Many studies of the geography of turnout are focused on local demographics correlations with turnout rates and changes $[22,26]$. One of the main features of turnout changes is the growing gap between young and older voters. It has clear political implications. For instance, in Brexit vote, turnout among 18-24 years old was 36 percent, while among older than 64-83 percent [17]. Kavanagh and Colleaques [20] for Ireland and Mansley and Demsar [22] for London reveal that territories with a higher share of older people in population structure have higher turnout. Agnew and Shin [3] in their study of the growing support for populists in Italy suggest that decrease in turnout shows rising dissatisfaction with politicians and creates a pool of nonvoters who are potential supporters of populists. They suggest that the decline in turnout is not just about age but also about generations and socialization into politics in time-space specific contexts. Darmofal [8] also suggests that local political setting is essential for turnout dynamics and he is critical of the studies based only on the analysis of population structure and socio-economic characteristics. In contrast to individual level sociological studies, he proposes political geography of macro-level and accentuates historical shifts in the geography of turnout in the US.

Urban-rural and center-periphery divisions in the levels of electoral participation are also of great interest for electoral geography. Kavanagh $[18,19]$ reveals ruralurban divide in Irish geography of turnout and supposes that it may be interpreted as (1) the effect of population structure, (2) a stronger sense of community and more pervasive participatory norms in the rural areas. He also assumes political alienation and social deprivation are essential for the studies of the decline in turnout. Studies of mobility and turnout support the idea of local contexts influence. For instance, Vallbe and Ferran [27] study of people's mobility influence on turnout show that less populated cities are environments where people who moved there vote more 
frequently than in bigger cities. Therefore, the urban-rural divide is not only about population structure. Consequently, geographical patterns of turnout support the idea about the crucial role of the age in turnout levels. However, supposed by Agnew and Shin [3] study of time-space specific contexts of generations socialization into participation in elections and Darmofal [8], Johnston and Pattie [14], and Kavanagh $[18,19]$ ideas about the impact of local contexts on turnout dynamics are of great interest for further political geography research of turnout.

Previously unresolved questions this paper is dedicated. Electoral geography studies of Ukraine are mostly focused on the impact of ethnicity, language, class, and region on electoral outcomes. Geography of turnout is only sometimes mentioned in the reviews of electoral outcomes and analyses of the factors influencing voting behavior in Ukraine [4, 6, 7, 12, 13, 21, 25]. At the same time, Johnston and Pattie [14] for Great Britain, Darmofal [8] for the US, Kavanagh [18, 19, 20] for Ireland, and Agnew and Shin [3] for Italy revealed essential geographical factor in turnout and accentuated the importance of turnout studies from geographical perspective. Although turnout in Ukraine is not so dramatically falling as in the Western democracies (Fig. 1), it is still a matter of concern as well as East-West and urbanrural divide in turnout.

The paper aims to reveal geographical patterns of turnout in Ukraine in 20022014 and starts a discussion about causes and consequences of the geography of turnout in the country as well as shows geographic patterns of the distribution of the votes below the threshold.

\section{DATA AND METHODS}

We gathered and geocoded data from Central Electoral Office of Ukraine about turnout in Ukraine in parliamentary elections of 2002, 2006, 2007, 2012, and 2014 at the level of the polling station. We also obtained statistics for 2002-2014 parliamentary elections turnout for 490 administrative rayons and 183 cities with special administrative status. Based on these data we analyzed geographical patterns of turnout in Ukraine in 2002-2014 parliamentary elections. We also used electoral outcomes data from Central Electoral Office for administrative rayons and cities with special administrative status to calculate the share of votes for parties who did not pass the electoral threshold for parliamentary elections 2002-2014 and analyzed geographical patterns of distribution of those votes that were not represented in the parliament. The studied period is limited to 2002-2014 because Central Electoral Office has data only for 1998-2014 elections, and 1998 and 1999 elections data are not aggregated at the level of administrative rayons and are not accessible at the level of the polling station, which were chosen as the levels of analysis. 


\section{RESULTS AND DISCUSSION}

Turnout in parliamentary and presidential elections in 1998-2014 in Ukraine is declining (Fig. 1). In parliamentary elections of 199863.8 percent of the voters participated in the elections, while in 2014 only 52.4 percent. Presidential elections turnout faces the same trend, in 199969.8 percent voted, while in 2014 only 59.5 percent. However, the decline for presidential elections is not linear and was the highest during the studied period in 2004 presidential elections second round. It follows theoretical assumption that less competitive elections have lower turnout. Moreover, 2004 was a year of intense polarization of the Ukrainian electorate and electoral fraud, which was also committed falsifying turnout at particular polling stations. Presidential elections first round have from 6 to 10 percent higher turnout than parliamentary elections in Ukraine, and the second round has higher turnout than the first from 2.4 to 6.3 percent. One of the assumptions about such difference is that differences between individual candidates in presidential elections are more evident for the electorate than differences between political parties. It is in touch with the personalization of politics and turn in electoral campaigns in parliamentary elections to focus on leaders and not on parties and their programs. Besides that difference in turnout in parliamentary and presidential elections, both faces almost 10 percent decline from 1998 to 2014. We should also pay attention to geographical differences of those changes (Fig. 2).

As we can see at Figure 2, in Ukraine turnout has a clear urban-rural divide. It is interesting that the gap between turnout in cities and periphery is narrowing. In parliamentary elections 2002, it was almost 13 percent, while in 2014 it is already only 5.1 percent. From 2002 to 2006 turnout in cities even increased by 0.1 percent, but in the 2006-2014 period is following the same trend as in the periphery but

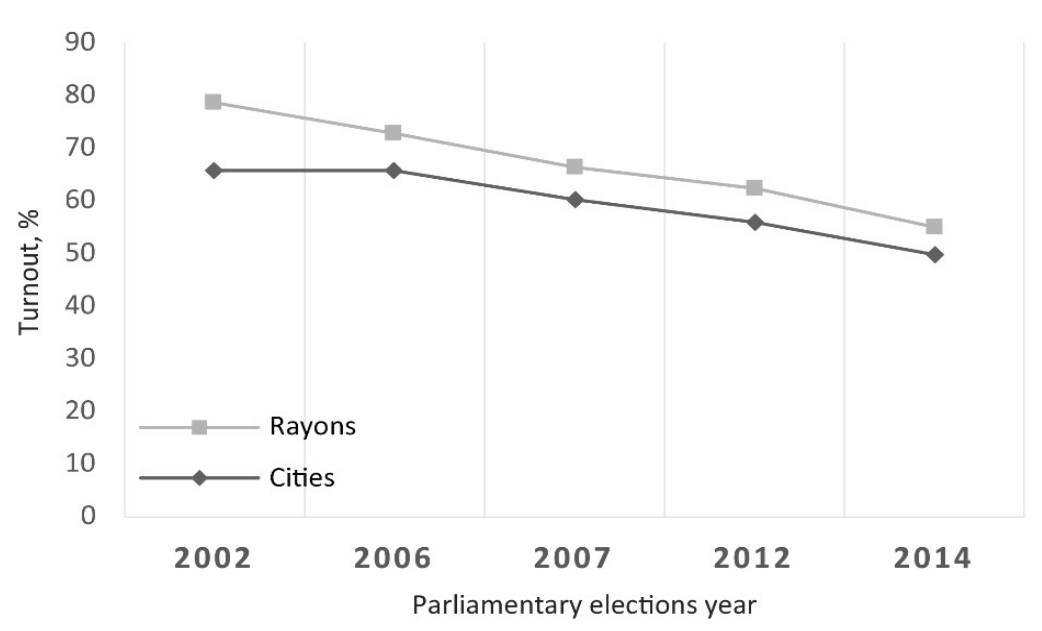

Fig. 2. Turnout in parliamentary elections in cities with special administrative status and rayons 
with lower intensity. We can speculate that changes in turnout from 2002 to 2006 in cities where caused by higher level of political mobilization in cities during Orange revolution in 2004 and turn back to decline in turnout from 2006 to 2007 was a result of dissatisfaction with politicians and absence of felt changes in quality of life, society, and economics after the revolution. Causes of the urban-rural divide in turnout might also have three assumptions. The first one suggests that it is a result of population structure: rayons have a higher share of the older population, while cities have a younger population and as we know older vote more frequently. The second assumes that cities in Ukraine have a significant inflow of the people from the periphery and mobile people have a lower level of electoral participation, which also might be because of studied by Vallbe and Ferran [27] effect of the size of the city on the turnout of the people who migrate. However, it also has a demographic variable: people who move to cities are younger, and their voting habits might have been not yet developed. The third hypothesis is that the periphery has more pervasive participatory norms and a stronger sense of community and obligation to vote. Moreover, people in the periphery might have more time resource to vote than their counterparts in cities. Those are only assumptions and need further empirical research to be tested.

The second division line in the geography of turnout in Ukraine is East-West divide. However, in 2002 parliamentary elections it was not so visible as in the following elections (Fig. 3). One of the reasons for such turn in electoral behavior might be weakened positions of the Communists, who have strong support in the 2002 parliamentary elections and only received 3.7 percent of the popular vote in 2006. Clem and Craumer [6, p. 145] reveal that Party of Regions had a statistically significant correlation coefficient $(-0.492)$ with the turnout in 2006 parliamentary elections, which means that they received most of the support in the areas were turnout declined. Consequently, it shows that part of the supporters of the Communist Party of Ukraine stayed home at the 2006 elections. However, reasons why people who were previously supporting Communists did not vote or shift their positions to Party of Regions or other third parties (for instance Socialists with left agenda) are not clear. At the same time, Donetsk and Lugansk oblasts have higher turnout than other territories of South and East Ukraine. They were strongholds of the Party of Regions, and it shows that the Regions had higher mobilization of the electorate rates at those administrative oblasts. Hypothetically it could be due to the mobilization of regional identity and friends and neighbors effect when people vote for those who live or were born near them. Therefore, friends and neighbors effect also might affect turnout. Moreover, East-West divide in turnout might be defined in the categories of political culture and differences in historical experiences of the territories. For instance, Zhukov and Talibova [30] reveal the long-term effect of Stalin's repressions on political participation in Russia and Ukraine.

The dynamics of turnout in Ukraine in 2002-2014 shows that three Galician oblasts have permanently high turnout (the highest in the country) with somewhat 
lower value in the 2012 parliamentary elections. From 2002 to 2014 visible is a decline in turnout in Volyn region, especially in its Polissya part, and North-East Ukraine. It is interesting that in 2012 parliamentary elections when Party of Regions won the elections, North-West Ukraine had lower turnout than in previous years. In 2014 Galicia increased turnout, while other areas of North-West Ukraine had no significant changes and only local variations were present. At the same time, in South and East Ukraine, despite some local variations, turnout was steadily declining in 2002-2014. However, local variations are also of great interest. For instance, our preliminary study of the turnout at the polling stations located in university campuses in Kyiv shows lower turnout in students' areas than the average in the city. It supports the thesis that younger people have lower turnout rates. However, there is also the dynamics of the mobilization of young people by political parties. In 2012 turnout in the campuses areas was closer to the average in the city than in 2002, 2006, 2007, and 2014 elections. It could be interpreted as an effect of particular political parties mobilization strategies. In the case of 2012 elections, UDAR and Svoboda received the highest support among the younger generation.
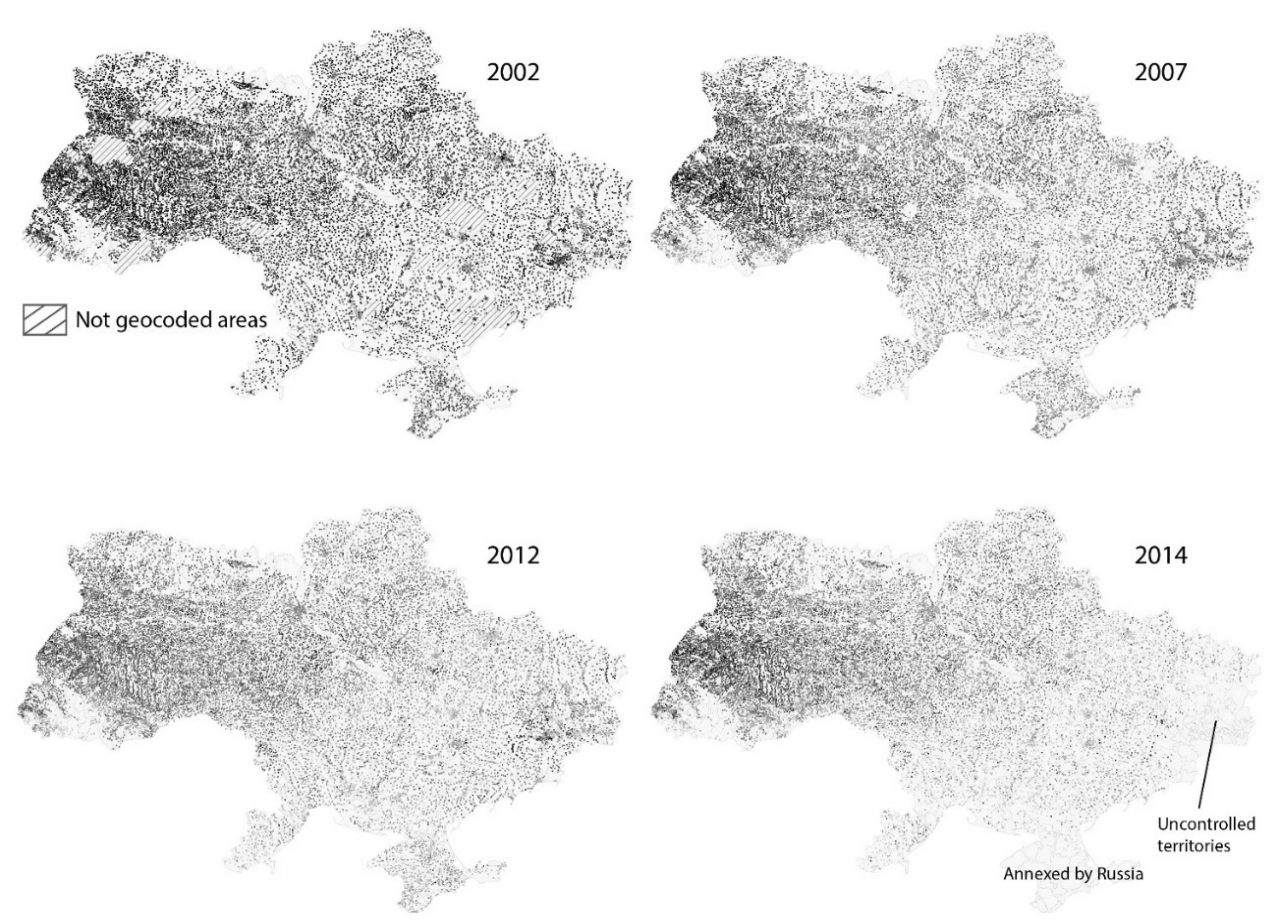

$\begin{array}{llllllll}0 \% & 40 \% & 50 \% & 60 \% & 70 \% & 80 \% & 90 \% & 100 \%\end{array}$

Fig. 3. Territorial patterns of turnout in parliamentary elections 2002-2012 at the level of the polling station (based on data from Central Electoral Office) 
Cartographic analysis also reveals that territories with higher shares of national minorities (Hungarians and Romanians in Zakarpattya oblast, Romanians and Moldovans in Chernivtsi oblast, Bulgarians, Moldovans, and Gagauz minorities in Odesa oblast) have lower turnout, which could be a sign of the absence of inclusion of ethnic minorities into Ukrainian politics and absence of political parties whose agenda, rhetoric and ideology are inclusive. Moreover, the cartographic analysis shows that those territories also vote more for the parties, which were below the threshold in 2002-2014 parliamentary elections (Fig. 4). Therefore, their representation in the parliament is only narrowed to majoritarian candidates elected from their constituencies, when Ukrainian electoral system was mixed (2002, 2012 and 2014 elections).
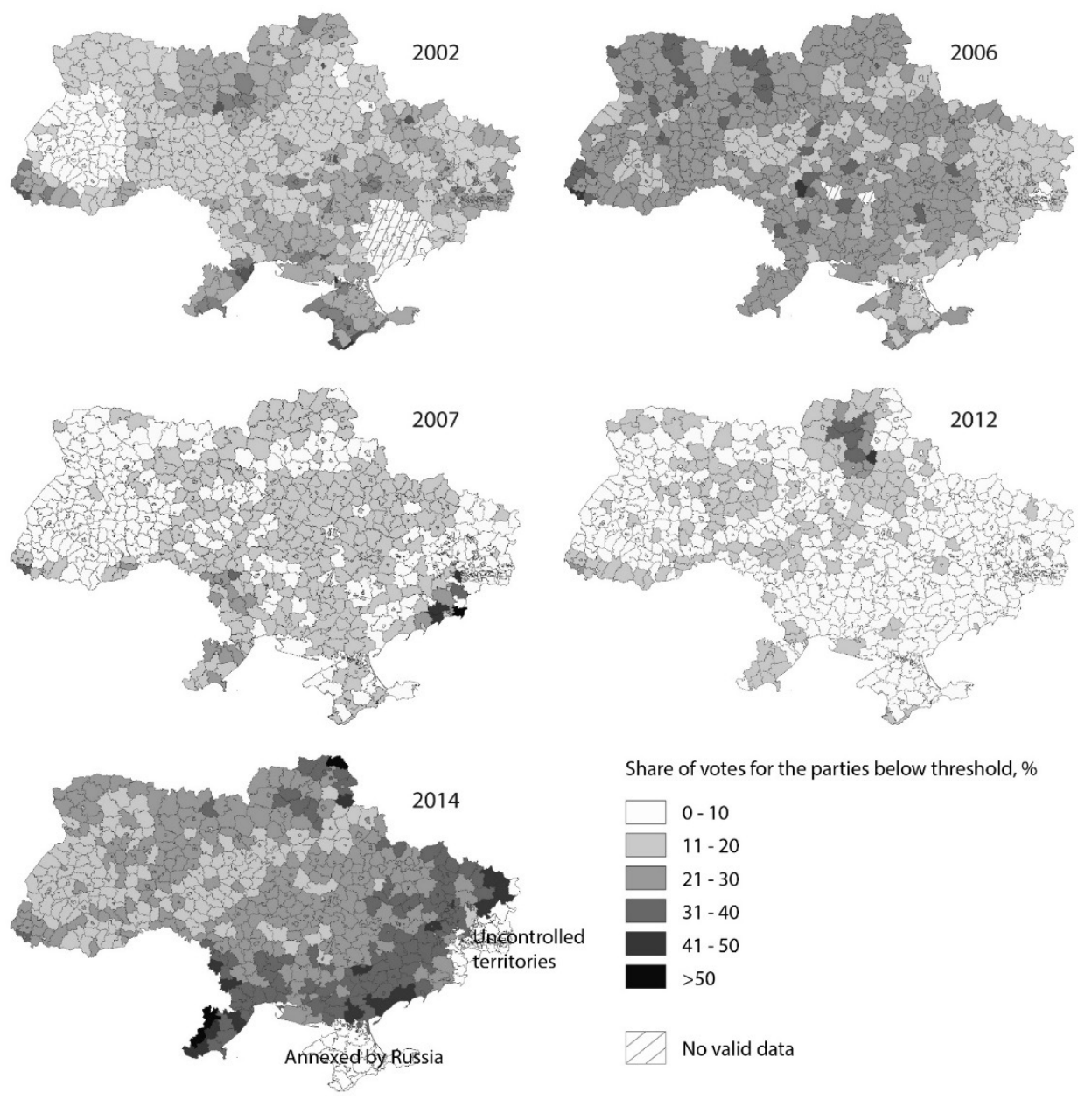

Share of votes for the parties below threshold, $\%$

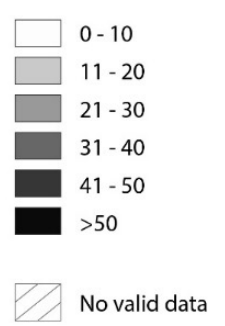

Fig. 4. The share of the votes for the parties below the threshold in parliamentary elections 2002-2014 at rayon and cities with special administrative status level (based on data from Central Electoral Office) 
Moreover, the geography of the unrepresented in the parliament votes shows polarization of electoral behavior from 2006 to 2012 because most of the votes were going to leading parties, which had a clear cleavage line, and not for the third parties who proposed alternatives. In 2012 parliamentary elections, we can also see a vivid result of constituency campaigning in majoritarian system influence on proportional electoral system results. Only Oleg Lyashko constituency and neighboring areas were supporting parties which did not win the seats in the parliament on a proportional basis. Oleg Lyashko was elected from the constituency on a majoritarian basis, and his party won elections in the constituency territory in the proportional part of elections, but it was not enough to reach the threshold at the national level. In 2014 parliamentary elections we can also see signs of East-West divide because many of the South and East Ukraine rayons and cities with special administrative status were voting for parties who did not win seats in the parliament on a proportional basis. Together with low turnout in those areas, it shows that they have no feeling of being represented in politics and might be further alienated from politics.

\section{CONCLUSION}

Elections being the main instrument of democracy are not obviously reflecting political preferences of the whole population of the country [9]. First, turnout reveals those who abstain because of dissatisfaction with politicians and parties or seeing no parties or candidates who represent their political beliefs or being alienated from politics. Second, not all of the votes turn into seats in the parliament. It is not only the question of the electoral law (algorithm how shares are turned into votes and threshold level) but also of electoral behavior and voting for parties, which did not reach a threshold. It shows that society has groups of people who are dissatisfied with existing popular options and political options they are ready to support have low national recognition and are not presented in the parliament. They might be mobilized by major political powers as is demonstrated by the polarization of Ukrainian politics in 2002-2012 or abstain from voting as in 2014. Ukraine has a clear East-West divide in turnout, which was intensified during polarization in 2002-2012 and might be interpreted in terms of political culture or alienation from politics because of the absence of options that represent political preferences of the population living in areas with lower turnout; rural-urban divide, which shows differences in population structure as well as participatory norms and local contexts; and lower turnout in territories where ethnic minorities live, which raises a question of their inclusion into Ukrainian politics and existing political opportunities for such inclusion. Cartographic analysis and analysis of the existing literature on the geography of turnout only demarcated issues and hypotheses about the geography of turnout in Ukraine, which should have an in-depth and thorough empirical examination in further studies. Turnout in Ukraine is also an issue of nation-building after the fall of the Soviet Union and the inclusion of different groups of the population into politics and constraints that alienation from politics, the vision of no difference between 
political parties or having no parties that represent people's political beliefs put on the further development of the country.

\section{REFERENCES}

1. Agnew, J. (1990), "From political methodology to geographical social theory? A critical review of electoral geography, 1960-1987" Developments in electoral geography, New York: Routledge, pp. $15-21$.

2. Agnew, J., Mamadouh, V., Secor, A., Sharp, J. (2015), The Wiley Blackwell Companion to Political Geography. Chichester, West Sussex: John Wiley \& Sons, 568 p.

3. Agnew, J., Shin, M. (2017), Spatializing Populism: Taking Politics to the People in Italy. Annals of the American Association of Geographers, 107 (4), pp. 915-933.

4. Bojcun, M. (1995), The Ukrainian Parliamentary Elections in March-April 1994. Europe-Asia Studies, 47 (2), pp. 229-249.

5. Clarke, H. D., Sanders, D., Stewart, M. C., \& Whiteley, P. (2004), Political Choice in Britain. Oxford University Press, $390 \mathrm{p}$.

6. Clem, R. S., Craumer, P. R. (2008), Orange, Blue and White, and Blonde: The Electoral Geography of Ukraine's 2006 and 2007 Rada Elections. Eurasian Geography and Economics, 49 (2), pp. 127- 151.

7. Craumer, P. R., \& Clem, J. I. (1999), Ukraine's Emerging Electoral Geography: A Regional Analysis of the 1998 Parliamentary Elections. Post-Soviet Geography and Economics, 40 (1), pp. $1-26$.

8. Darmofal, D. (2006), The political geography of macro-level turnout in American political development. Political Geography, 25 (2), pp. 123-150.

9. Fowler, A. (2014), Regular Voters, Marginal Voters and the Electoral Effects of Turnout. Political Science Research and Methods, First View (May), pp. 1-15.

10. Franklin, M. N. (2002), The Voter Turnout Puzzles. Available at: http://citeseerx.ist.psu.edu/ viewdoc/download? doi=10.1.1.7.1663\&rep=rep1\&type=pdf. [Accessed 12 October 2018].

11. Franklin, M. N., Lyons, P., Marsh, M. (2004), Generational Basis of Turnout Decline in Established Democracies. Acta Politica, 39 (2), pp. 115-151.

12. Harasymiw, B. (2005), Elections in Post-Communist Ukraine, 1994-2004: An Overview. Canadian Slavonic Papers, 47 (3-4), pp. 191-239.

13. Herron, E. S. (2011), How Viktor Yanukovych won: Reassessing the dominant narratives of Ukraine's 2010 presidential election. East European Politics and Societies, 25 (1), pp. 47-67.

14. Johnston, R. J. \& Pattie, C. J. (2006), Putting voters in their place : geography and elections in Great Britain. Oxford University Press, $336 \mathrm{p}$.

15. Johnston, R. J., Pattie, C. J. (2001), "It's the Economy, Stupid" - But Which Economy? Geographical Scales, Retrospective Economic Evaluations and Voting at the 1997 British General Election. Regional Studies, 35 (4), pp. 309-319.

16. Johnston, R. J., Shelley, F. M., Taylor, P. J. (1990), "Developments in Electoral Geography" Developments in Electoral Geography. New York: Routledge, pp. 1-14.

17. Johnston, R., Jones, K., Manley, D. (2016), The geography of the Brexit vote - what difference will turnout make? Available at: http://eprints.lse.ac.uk/71271/. [Accessed 12 October 2018].

18. Kavanagh, A. (2002), Social Deprivation, Political Alienation and Community Empowerment.The geography of voter turnout in Ireland,1997-2002, and its Association with Social Deprivation, Doctor's dissertation, National University of Ireland Maynooth: NUI Maynooth, $560 \mathrm{p}$.

19. Kavanagh, A. (2002), Unequal Participation-Unequal Influence: Voter Participation and Voter Education in Dublin's South West Inner City, Dublin: South West Inner City Network, 117 p.

20. Kavanagh, A., Mills, G., Sinnott, R. (2004), The geography of Irish voter turnout: A case study of the 2002 general election. Irish Geography, 37 (2), pp. 177-186. 
21. Kubicek, P. (2000), Regional Polarisation in Ukraine: Public Opinion, Voting and Legislative Behaviour. Europe-Asia Studies, 52 (March 2015), pp. 273-294.

22. Mansley, E., Demšar, U. (2015), Space matters: Geographic variability of electoral turnout determinants in the 2012 London mayoral election. Electoral Studies, 40, 322-334.

23. Norris, P. (2002), Democratic Phoenix: Reinventing Political Activism. Cambridge University Press, $290 \mathrm{p}$

24. Pattie, C., Seyd, P., Whiteley, P. (2004), Citizenship in Britain: Values, Participation and Democracy. Cambridge University Press, 364 p.

25. Shevel, O. (2015), The parliamentary elections in Ukraine, October 2014. Electoral Studies, 39(October 2014), pp. 159-163.

26. Taylor, K., Combs, H. J., Burger, P. R. (2016), A GIScience Approach to Analyzing Spatial Patterns of Voter Turnout in Omaha, Nebraska. Geographical Bulletin, 57 (2), pp. 99-114.

27. Vallbé, J.-J., Magre Ferran, J. (2017), The Road Not Taken. Effects of residential mobility on local electoral turnout. Political Geography, 60, pp. 86-99.

28. Verba, S., Schlozman, K. L., Brady, H. E. (1995), Voice and equality : civic voluntarism in American politics. Cambridge, Mass.: Harvard University Press, 640 p.

29. Warf, B., \& Leib, J. (Eds.), (2011), Revitalizing Electoral Geography. Padstow, Cornwall: Ashgate, $238 \mathrm{p}$.

30. Zhukov, Y. M., \& Talibova, R. (2018), Stalin's terror and the long-term political effects of mass repression. Journal of Peace Research, 55 (2), pp. 267-283.

Надійшла 21. 09. 2018

М. П. Добиш, аспірант

Київський національний університет імені Тараса Шевченка,

Проспект Глушкова, 2, Київ, 03127, Україна

mpetrovych@gmail.com

\section{ТЕРИТОРІАЛЬНІ ЗАКОНОМІРНОСТІ ЯВКИ \\ ТА РЕПРЕЗЕНТАЦІЇ НА ПАРЛАМЕНТСЬКИХ ВИБОРАХ 2002-2014 РОКІВ В УКРАЇНI}

\section{Резюме}

Постановка проблеми та мета статmі. Географія явки на виборах знаходиться на периферії географічних досліджень електоральної поведінки населення. Однак, останні дослідження географічних закономірностей падіння рівня явки на виборах та iï динаміки в країнах Заходу показують важливість розуміння контексту часу та географічного місця у рішенні голосувати чи ні. В Україні немає географічних досліджень присвячених виключно питанню явки на вибоpax, тому стаття має за мету заповнити цю прогалину і почати дискусію щодо розуміння територіальних закономірностей явки на парламентських виборах в Україні в 2002-2014 роках.

Дані та методи. Стаття досліджує географію явки на виборах в Україні, базуючись на даних на рівні виборчих дільниць та районів $(\mathrm{n}=490)$ і міст обласного підпорядкування (n=183) для парламентських виборів 2002, 2006, 2007, 2012 
та 2014 років. Ми здійснили картографічний аналіз явки на виборах на рівні виборчих дільниць та географії голосів відданих за партії, які не проходили в парламент в досліджуваний період на рівні районів та міст обласного підпорядкування.

Результати. Картографічний аналіз показує вагомо нижчий рівень явки в південно-східній Україні, що стало більш видимим після виборів 2002 року; значно нижчий рівень явки у містах порівняно з периферією; нижчу явку на територіях, де проживають національні меншини. Ця ситуація ускладнюється тим, що на парламентських виборах 2014 року населення південно-східної України віддало значну частку голосів партіям, які не пройшли в парламент і вищий рівень підтримки таких партій на територіях проживання етнічних меншин в 2002- 2014 роках. Стаття також показує, що в 2002-2014 роках різниця у явці між містами та сільською місцевістю зменшувалася за рахунок нижчого рівня спаду явки на урбанізованих територіях. Ба більше, в 2006 році, порівняно 3 2002 роком, явка в містах обласного підпорядкування зросла, тоді коли на периферії вона стрімко знижувалася. Стаття розпочинає дискусію щодо причини та наслідків територіальних особливостей явки на виборах та їі динаміки в Україні.

Ключові слова: зниження явки на виборах, географія явки на виборах, географія репрезентації, територіальні закономірності явки на виборах в Україні.

Н. П. Добиш, аспирант

Киевский национальный университет имени Тараса Шевченко

Проспект Глушкова, 2, Киев, 03127, Украина

mpetrovych@gmail.com

\section{ТЕРРИТОРИАЛЬНЫЕ ЗАКОНОМЕРНОСТИ ЯВКИ И РЕПРЕЗЕНТАЦИИ НА ПАРЛАМЕНТСКИХ ВЫБОРАХ 2002-2014 ГОДОВ В УКРАИНЕ}

География явки на выборах находиться на периферии географических исследований электорального поведения, несмотря на последние исследования территориальных закономерностей снижения явки на выборах и ее динамики в странах Запада, которые раскрывают важность понимания контекста времени и географического места в решении голосовать или нет. Следовательно, в статье поднимается вопрос об исследовании географии явки на выборах в Украине. Статья опирается на данные на уровне участков для голосования, районов и городов областного подчинения. Картографический анализ показывает более низкий уровень явки на юго-востоке Украины, что стало более видимым после выборов 2002 года; более низкий уровень явки в городах по сравнению с периферией; низкую явку на территориях, где проживают национальные меньшинства. Ситуация усугубляется тем, что на парламентских выборах 2014 года население юго-востока страны отдало значительную часть голосов за партии непрошедшие в парламент. То же можно сказать и о территориях, где проживают 
национальные меньшинства, но касательно не только 2014, а 2002-2014 годов. Статья также начинает дискуссию о причинах и следствиях территориальных особенностей явки на выборах и ее динамики в Украине.

Ключевые слова: снижение явки на выборах, география явки на выборах, география репрезентации, территориальные закономерности явки на выборах в Украине. 